\author{
BULETINUL INSTITUTULUI POLITEHNIC DIN IAŞI \\ Publicat de \\ Universitatea Tehnică „Gheorghe Asachi” din Iaşi \\ Volumul 67(71), Numărul 1, 2021 \\ Secţia \\ CONSTRUCTTII. ARHITECTURĂ \\ DOI: 10.2478/bipca-2021-0009 \\ sciendo
}

\title{
NOTES ABOUT CRUSHING SAND FROM BITUMINOUS SCHIST
}

BY

\section{DUMITRU-DRAGOS HANGANU*}

\author{
„Gheorghe Asachi” Technical University of Iaşi, Faculty of Civil Engineering and Building
} Services, Iasi, Romania

Received: January 18, 2021

Accepted for publication: March 28, 2021

\begin{abstract}
People have used sand and stone for foundations for thousands of years. Significant refinement of the production and use of aggregate occurred during the Roman Empire, which used aggregate to build its vast network of roads and aqueducts. The invention of concrete, which was essential to architecture utilizing arches, created an immediate, permanent demand for construction aggregates.

Construction aggregate, or simply "aggregate", is a broad category of coarse to medium grained particulate material used in construction, including sand, gravel, crushed stone, slag, recycled concrete and geosynthetic aggregates. Aggregates are the most mined materials in the world. Aggregates are a component of composite materials such as concrete and asphalt concrete; the aggregate serves as reinforcement to add strength to the overall composite material. Due to the relatively high hydraulic conductivity value as compared to most soils, aggregates are widely used in drainage applications such as foundation and French drains, septic drain fields, retaining wall drains, and roadside edge drains. Aggregates are also used as base material under foundations, roads, and railroads. In other words, aggregates are used as a stable foundation or road/rail base with predictable, uniform properties (e.g. to help prevent differential settling under the road or building), or as a low-cost extender that binds with more expensive cement or asphalt to form concrete.

Preferred bituminous aggregate sizes for road construction are given in EN 13043 as d/D (where the range shows the smallest and largest square mesh grating that the particles can
\end{abstract}

\footnotetext{
* Corresponding author;e-mail: dumitru-dragos.hanganu@student.tuiasi.ro (C) 2021 Dumitru-Dragos Hanganu.

This is an open access article licensed under the Creative Commons Attribution-NonCommercialNoDerivatives 4.0 International License (CC BY-NC-ND 4.0).
} 
pass). The same classification sizing is used for larger armour stone sizes in EN 13383, EN 12620 for concrete aggregate, EN 13242 for base layers of road construction and EN 13450 for railway ballast.

Aggregates themselves can be recycled as aggregates. Unlike deposits of sand and gravel or stone suitable for crushing into aggregate, which can be anywhere and may require overburden removal and/or blasting, "deposits" of recyclable aggregate tend to be concentrated near urban areas, and production from them cannot be raised or lowered to meet demand for aggregates. Supply of recycled aggregate depends on physical decay of structures and their demolition. The recycling plant can be fixed or mobile; the smaller capacity mobile plant works best for asphalt-aggregate recycling. The material being recycled is usually highly variable in quality and properties.

Key words: Aggregates, bituminous aggregate, sand, gravel, crushed stone

\section{Introduction}

Bituminous schist is an argillaceous shale that contains bitumen, a mixture of hydrocarbons that may be used as fuel, as a paving material, or in a number of other applications. Formed through the consolidation of silt or clay particles, shale is a common sedimentary rock that readily cleaves into thin layers along lines parallel to its bedding planes. The rock is most often gray in color, but may exhibit a range of hues due to the varying composition of the rock. This type of shale is often found accompanying coal and, in fact, grades into bituminous coal when carbonaceous material is present in large amounts. Humans have utilized bituminous shale at various periods throughout history, though at some times much more heavily than others. In the Kimmeridge Bay area of Dorset, England, for instance, the material was used as a fuel and as a material for craftsmen even in pre-Roman times, though the Romans were responsible for the first large-scale operations in the area. Also, many years later, in 1851, Canadian geologist Abraham Gesner patented a process for extracting kerosene, which could be burned for lighting, from bituminous shale.

When bituminous shale contains kerogen it is better known as oil shale. Kerogen is a chemically complex mixture of hydrocarbons derived from organic material that can be heated to yield oil. Typically, this production of oil, which is generally referred to as syncrude, takes place at about 500 degrees Celsius. One of the earliest known references to the extraction of oil from shale was made in 1596 by a physician who claimed that the substance distilled from the rock could be utilized for healing purposes. About a century later, the first known commercial shale oil industries were developed, many of which were successful for a number of years. However, as discoveries of crude oil were made in various locations around the world, the vast majority of these operations closed down since oil fields were a much more economic source of oil than shale. 


\section{The role of crushing sand from bituminous schist}

The main purpose of this research is to analyse the influence of different natural aggregate sources, as well as different bitumen types, on the adhesion and affinity between the two materials and on the properties of stone mastic asphalt (SMA). The aggregates used in this study were both fine (sand 0/4) and coarse (4/8 and 8/16), extracted from four different natural rock, selected after a geographical, geological and geomorphological analysis. From a petrographic point of view, the rocks extracted in the proposed quarries are igneous. Adhesion and affinity tests on bitumen coated aggregates were performed, while also employing an antistripping agent in the process. Regular paving grade bitumen 50/70, as well as polymer modified bitumen (PMB) 45/80-65, were used. All tests have shown that using an antistripping agent improves both bitumen adhesion to natural aggregates and the affinity between the two. Afterwards, laboratory tests on SMA samples, prepared using the same types of bitumen, aggregates and additive, were performed. Although the results were variable and no general conclusion could be drawn, they were clearly influenced by the shape and nature of the mineral aggregates, as well as by the bitumen types and grades.

Rock materials used in this study (Fig. 1) were obtained from rock masses in the Neamt county, Nechit Village in north estern Romania (Fig. 2).

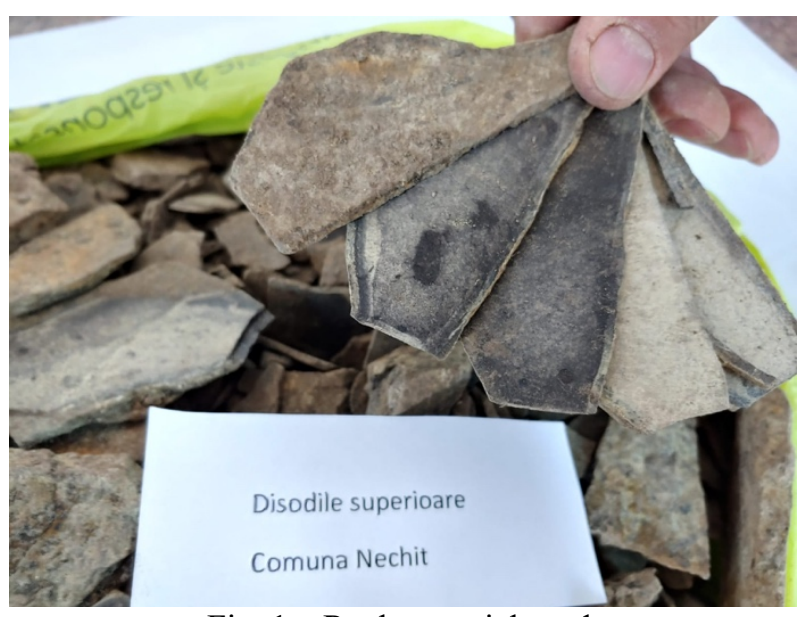

Fig. 1 - Rock material used. 


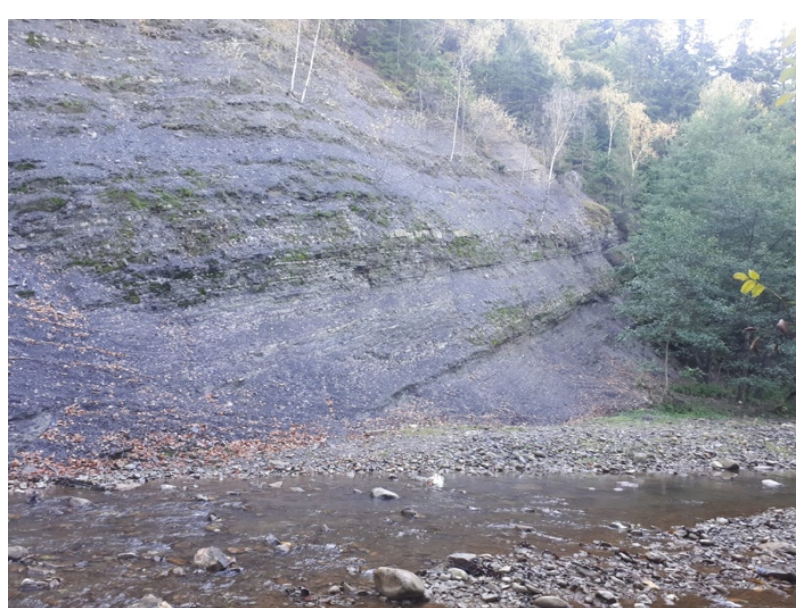

Fig. 2 - Rock masses in the Neamt county, Nechit Village

Furthermore, the selection was influenced by several issues (i.e., low rock density, high Los Angeles abrasion and terrace extraction sites) which restricted the quarry selection options. www.sgem.org Geology From a petrographic point of view, the aggregates used in this study are igneous, formed through the cooling and solidification of magma derived from Earth's superior mantle. They are the result of a sequential natural magma crystallisation, which determines the rock structure and texture, depending on the cooling time.

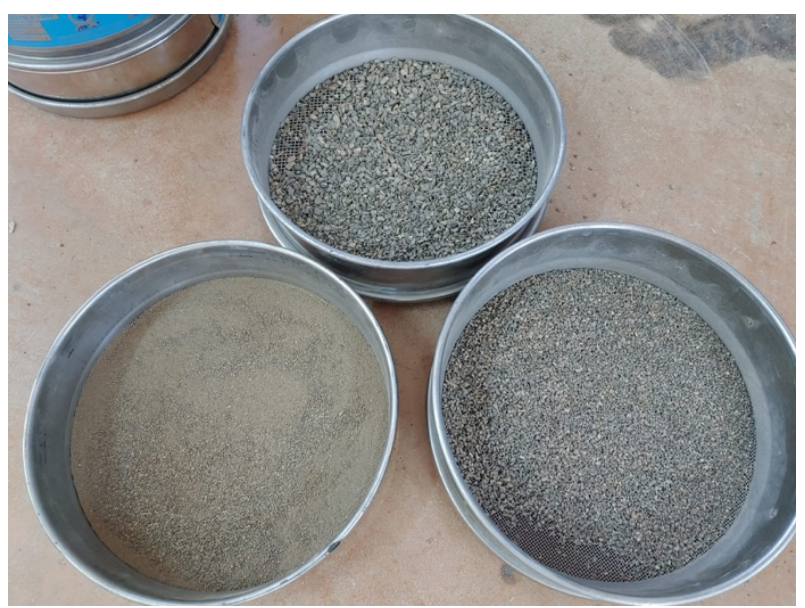

Fig. 3 - Aggregates used in this study

Diabase is a fine-grained rock, composed mostly of pyroxene and feldspar. It resembles andesite in several aspects, including hardness, both rocks being much more resistant than dacite. However, they are all durable rocks. The composition of dacite is an intermediate between andesite and 
rhyolite. The aggregates used in this study (Fig. 3) were both fine (sand $0 / 4$ ) and coarse (4/8 and 8/16), consisting of polyhedric stones obtained through crushing and sorting of the extracted mineral deposits. The quarry test reports indicated that the aggregates geometrical and physiomechanical properties met the standardised technical quality requirements.

This research has shown that the properties of an bituminous schist, with particular focus on the aggregate-bitumen adhesion, are influenced by the natural aggregates, bitumen types and additives it contains. Bitumen adhesion to andesite aggregates from source no. 2 was better compared to other aggregates. Using PMB and anti-stripping agent generally improved the aggregate-bitumen bond. An exception was noted in the case of diabase aggregates, for which SRB manifested improved adhesion. The specific reasons for this behaviour was not analysed in this study. The same conclusions apply to the affinity between aggregates and bitumen. Aggregates in the asphalt mixture composition did not influence the void content reduction brought by replacing SRB with PMB. Dacite provided the lowest void content (when using PMB), whereas andesite from source no. 2 led to slightly increased values. Dacite aggregates also led to low asphalt mixture permanent deformation speed, but, at the same time, to high rut depth. Deeper ruts were recorded for SMAs prepared with diabase aggregates as well. As Pop et al. have shown, using PMB reduces the asphalt mixture stiffness. In this study, andesite aggregates from source no. 1 led to increased stiffness moduli compared to the other aggregates.

\section{Conclusions}

Aggregates are principal materials in pavement. They are often used in either stabilized or unstabilized base or sub-base courses. Knowledge of aggregate properties is crucial to designing a high quality pavement. Results of this work will be useful in selecting the rock types to quarry for the production of aggregates for optimum use in sustainable road construction.

Acknowledgements.

Regards to professor Grasu Constantin, who helped me to find the area were I can find the bituminous schist.

\section{REFERENCES}

Gugiuman, Gh. The Usage of Bituminous Sands in Road Pavement Asphalt Mixtures Composition, Internat. Sci. J. Trans \& MOTAUTO WORLD, year I, ISSUE 2/2016, ISSN 2367-8399, Scientific Technical Union of Mechanical Engineering, 40-42 (2016). 
Nicoara L., Paunescu M., Bob C., Bilsiu A., Indrumatorul laboratorului de drumuri,Edit.Tehnica, Bucuresti, 1985.

Probstein F.R., Hicks E.E., Synthetic Fuels, Oil Shale and Tar Sands, Dover Publication Inc, New York, 183-184, 2006.

Vrtis C.M., Creating a Performance - Based Asphalt Mix Design to Incorporate Uinta

Basin Oil Sands, Master thesis, Departament of Civil and Environmental

Engineering, The University of Utah, 2013.

Normativ departamental pentru folosirea directa a nisipurilor bituminoase cu sifara adaos de bitum dur la executarea la cald a straturilor bituminoase rutiereCD 42-85, Bucuresti, 1985.

Normativ privind mixturile asfaltice executate la cald. Conditii tehnice privindproiectarea, prepararea si punerea în opera, Indicativ 605-2014, Bucuresti,2014.

\section{NISIPUL DE CONCASARE DIN ȘISTURI BITUMINOASE}

(Rezumat)

Cresterea progresiva a cererii pentru mixturi asfaltice, si în consecinta pentru bitumul rutier, corelata cu deficitul cantitativ si calitativ al acestui material esential la realizarea lucrarilor de drumuri, au reliefat importanta utilizarii la prepararea amestecurilor bituminoase de componenti neconventionali, cum ar fi șisturile bituminoase. Utilizarea a şisturilor bituminoase este impusa de cresterea semnificativa a pretului liantilor bituminosi, concomitent cu degradarea treptata a retelei de drumuri din România, precum si cu sporirea gradului de motorizare si, asadar, a limitarii posibilitatilor de reabilitare datorata costurilor ridicate. Prin încorporarea a șisturilor bituminoase în amestecul asfaltic se realizeaza o reducere semnificativa a cantitatii de bitum utilizata în mod conventional, liant care în momentul de fata este adus doar din import.

Necesitatea folosirii nisipurilor şi a şisturilor bituminoase din România la prepararea mixturilor asfaltice este impusa de costurile tot mai ridicate aferente bitumului rutier, material adus doar din import la momentul actual în țara noastra. 